\author{
Case Study
}

\title{
EFFECTIVE MANAGEMENT OF CHRONIC KIDNEY DISEASE BY USING AYURVEDIC INTERVENTIONS: A CASE REPORT
}

\section{Ajeet Pratap Singh, Manish Grover, Avira Gautam*}

*Shuddhi Ayurveda, Jeena Sikho Lifecare Pvt. Ltd. Chandigarh, Punjab, India.

\section{Article info \\ Article History: \\ Received: 17-07-2021 \\ Revised : 31-07-2021 \\ Accepted: 05-08-2021 \\ Published: 25-08-2021}

\section{KEYWORDS:}

Chronic Kidney Disease, Ayurveda, Mutraghat,

Hemodialysis.

\begin{abstract}
Renal failure causes a significant rise in the creatinine level, urea nitrogen, fluctuation in serum potassium and high sodium level in the blood. In 2017, 1.2 million deaths of CKD were reported world widely. Kidney transplant, peritoneal dialysis and hemodialysis are some modern methods used to treat renal failure in allopathy. These therapies and treatment are very expensive and unaffordable by the people of low income and middle-income countries. In India, Ayurveda is a conventional practice which is used since ancient times to treat number of disorders without any side effects. A case report of renal failure patient using Ayurvedic treatment is well defined here. A 53-year-old married Sikh, non-alcoholic, nonsmoking male diagnosed with renal failure presented in the Divya Upchar Sansthan, Chandigarh on October 2020. The patient was clinically assessed by Jeebha pariksha (tongue examination) and Naadi pariksha (pulse examination). Patient was administered with Ayurvedic medicines for the duration of six month of treatment. Patient was investigated for the functioning of kidney and hemoglobin before and after initiating Ayurvedic treatment which indicated an improvement in urea, creatinine and uric acid level. From this case study it is shown that chronic kidney disease can be managed by using Ayurvedic treatment without the need of hemodialysis.
\end{abstract}

\section{INTRODUCTION}

Renal failure is a kidney disorder which is caused by a significant reduction in the glomerular filtration rate (GFR)[1]. It is a growing issue and the most undocumented cause of premature mortality in middle-income and low-income countries. Renal failure causes a significant rise in the creatinine level, urea nitrogen, fluctuation in serum potassium and high sodium level in the blood. In 2017, 1.2 million deaths of CKD were reported world widely. Globally, the all age mortality rate has increased to $41.5 \%$ from 1990 to 2017[2]. The factors responsible for renal failure are imbalance diet, nephrotoxic drugs like NSAID, HTN (hypertension), diabetes etc. In India, the primary cause of both acute and chronic kidney disorder are environmental pollutants and toxins [2].

\begin{tabular}{|l|l|}
\hline \multicolumn{3}{|c|}{ Access this article online } \\
\hline Quick Response Code & https://doi.org/10.47070/ijapr.v9i7.1979 \\
\hline & $\begin{array}{l}\text { Published by Mahadev Publications (Regd.) } \\
\text { publication licensed under a Creative } \\
\text { Commons Attribution-NonCommercial- } \\
\text { ShareAlike 4.0 International (CC BY-NC-SA }\end{array}$ \\
\hline
\end{tabular}

In southern and eastern states of India, the rate of renal deaths was highest in 2010-2013. The most prominent age group was 45-69. The other diseases associated which significantly increased the rate of renal failure deaths were hypertension, diabetes (strongest cause of renal failure) and cardiovascular disorders. A significant rise in the mortality rate from the year 2000 to 2019 has been noticed i.e. 813,000 to 1.3 million. As per WHO, chronic kidney disorder is rated as the $10^{\text {th }}$ leading cause of death in 2020 [3]. In the forthcoming years, it is estimated that CKD will be the fifth leading cause of death by 2040[4]. It was reported that, nearly 2.5 million people are taking renal replacement therapy and is predicted to exceeds up to 5.4 million by 2030[5]. Kidney transplant, peritoneal dialysis and hemodialysis are some modern methods used to treat renal failure in allopathy. These therapies and treatment are very expensive and unaffordable by the people of low income and middleincome countries. In India, Ayurveda is a conventional practice which is used since ancient times to treat number of disorders without any side effects. Chronic kidney disease is featured with Mutraghat/Aama in Mutra vaha strotas (obstructive and suppressive 
uropathies) which hampers the kidney function as per Ayurveda. This disease is generated due to imbalance in the three Doshas of the body i.e. Vata, Pitta and Kapha. Ayurveda believes in holistic approach. There is no particular evidence or data available which suggests the effective use of Ayurveda in the treatment of Kidney failure. Besides, various Ayurvedic practitioner's claims that renal failure can be treated using Ayurvedic medicines. A case report of renal failure patient using Ayurvedic treatment is well defined.

\section{Case Report}

A 53-year-old married Sikh, non-alcoholic, nonsmoking male diagnosed with renal failure presented in the Divya Upchar Sansthan, Chandigarh on October 2020, with symptoms like uremia, indigestion, severe constipation, hypercreatinemia, irregular sugar, pitting edema over ankle joint, hyperuricemia, anemia, fatigue, gradual weight loss, anorexia. The patient was suffering from these symptoms from the past two years and also had a family history of hypertension. He was also diagnosed previously with diabetes mellitus, hypertension and renal failure from last 5-6 years. The patient was on allopathic medication for the same conditions but didn't get any relief. Even the patient was advised for weekly hemodialysis for kidney failure for which he refused and approached Divya Upchar Sansthan for its Ayurvedic management.

\section{Patient Information}

\section{Presenting complaints}

The chief complaints were diabetes mellitus, hypertension and renal failure.

\section{Medical, family and psychosocial history including genetic information}

The patient represented no history of drug intake or any other kind of addiction. The patient's father had a history of hypertension. There was no any other medical or genetic history in the family.

\section{Relevant past interventions and their outcomes}

There was no any previous surgical history of the patient.

\section{Clinical findings}

\section{Physical and Systemic Examination}

Initially, patient's systolic and diastolic blood pressure was recorded as 194/96 with pulse rate of 77 which was the clear indication of hypertension. His oxygen saturation level was also found to be $100 \%$. The patient was systemically examined for his bowel (frequency and evacuation), appetite and digestion, gas, acidity, eyes, urine, sleep and mind. From the assessment it was observed that:

- Hard bowel with complete evacuation.

- The episodes of tightness before the next meal

- Easy passing of gas

- Herat burn

- Yellowish eyes

- Yellow frothy urine

- Sound sleep

- Restlessness along with the episodes of anxiety.

\section{Clinical Assessment}

The patient was clinically assessed by Jeebha pariksha (tongue examination) and Naadi pariksha (pulse examination).

Jeebha Pariksha (Tongue examination)

\begin{tabular}{|l|l|l|l|l|l|}
\hline $\mathbf{1}^{\text {st }}$ Month & $2^{\text {nd }}$ Month & $\mathbf{3}^{\text {rd }}$ Month & $\mathbf{4}^{\text {th }}$ Month & $\mathbf{5}^{\text {th }}$ Month & $\mathbf{6}^{\text {th }}$ Month \\
\hline White & Patchy & Patchy & $\begin{array}{l}\text { Appears normal } \\
\text { with no coating }\end{array}$ & $\begin{array}{l}\text { Mild reduction } \\
\text { in patches }\end{array}$ & $\begin{array}{l}\text { Mild white } \\
\text { Patch }\end{array}$ \\
\hline
\end{tabular}

Naadi Pariksa (Pulse Examination)

\begin{tabular}{|l|l|l|l|l|l|l|}
\hline Naadi & $\mathbf{1}^{\text {st }}$ Month & $\mathbf{2}^{\text {nd }}$ Month & $\mathbf{3}^{\text {rd }}$ Month & $\mathbf{4}^{\text {th }}$ Month & $5^{\text {th }}$ Month & $\mathbf{6}^{\text {thMonth }}$ \\
\hline Vata & Moderate $(++)$ & Moderate $(++)$ & Moderate $(++)$ & Moderate $(++)$ & Low $(+)$ & Low $(+)$ \\
\hline Pitta & Low (+) & Low (+) & Low (+) & Low (+) & Moderate $(++)$ & Low $(+)$ \\
\hline Kapha & Moderate $(++)$ & Moderate $(++)$ & Moderate $(++)$ & Moderate $(++)$ & Low $(+)$ & Low $(+)$ \\
\hline
\end{tabular}

Indications: $(+++)$ High force (Bala), $(++)$ Moderate force (Bala), $(+)$ Low force (Bala).

\section{Dashvidh Pariksha}

- Prakriti (physical constitution):- Vata pitta prakrati

- Dosha (deranged regulatory functional factors of the body):- Pitta and Vata prakopa

- Dushya (deranged major structural components of the body):- Rakta and Meda dusti

- Sthana (site of localization):- Yakrut and Vrukka

- Agni (digestive/metabolic factors):- Mandagani

- Srotas (structural or functional channels):- Medovaha shrotas and Raktavaha shrotas

- Avastha (stage of disease):- Jirna avastha 
- Rogamarga (pathway of disease manifestation):- Abhyantar marga

- Sadhyaasadhyata (prognosis):- Ashadhya-yapya Aswastha

- Sara (excellence of tissues):- Madhyam sara

- Samhanana (body compactness):- Madhyam samhanna

- Pramana (measurements of body parts):- Madhyam praman

- Satmya (homologation):- Avra satmya

- Sattva (mental constitution):- Avara sattva

- Aharashakti (capacity to ingest food and capacity to digest and assimilate the food):- Madhya

- Vyayamashakti (capacity to exercise):- Avara (poor)

- Vaya (age) Madhyam yuvan avastha

\section{Laboratory Assessment}

Patient was investigated for the functioning of kidney and hemoglobin before and after initiating Ayurvedic treatment which indicated an improvement in urea, creatinine and uric acid level. Laboratory test results are compiled in table no. 1 and 2 respectively.

Table 1: Renal Function Test reports for the case report

\begin{tabular}{|l|l|l|l|l|l|l|l|}
\hline Test & $\begin{array}{l}\mathbf{1 6} \text { Nov. } \\
\mathbf{2 0 2 0}\end{array}$ & $\begin{array}{l}\mathbf{0 6} \text { Dec. } \\
\mathbf{2 0 2 0}\end{array}$ & $\begin{array}{l}\mathbf{2 4} \text { Dec. } \\
\mathbf{2 0 2 0}\end{array}$ & $\begin{array}{l}\mathbf{2 5} \text { Jan. } \\
\mathbf{2 0 2 1}\end{array}$ & $\begin{array}{l}\mathbf{1 1} \text { March } \\
\mathbf{2 0 2 1}\end{array}$ & $\begin{array}{l}\mathbf{1 7} \text { April } \\
\mathbf{2 0 2 1}\end{array}$ & $\begin{array}{l}\mathbf{2 8} \text { May } \\
\text { 2021 }\end{array}$ \\
\hline Urea (mg/dl) & 215.30 & 162.70 & 89.4 & 80.7 & 68.2 & 81.9 & 89 \\
\hline Creatinine (mg/dl) & 7.00 & 6.50 & 4.42 & 4.3 & 4.59 & 4.67 & 4.4 \\
\hline Uric acid (mg/dl) & 8.20 & 8.90 & 6.98 & 7.22 & 7.85 & 7.91 & 5.4 \\
\hline
\end{tabular}

Table 2: Hemoglobin and Blood Glucose Test Reports

\begin{tabular}{|l|l|l|l|l|l|l|l|}
\hline Test & $\begin{array}{l}\text { 16 Nov. } \\
\mathbf{2 0 2 0}\end{array}$ & $\begin{array}{l}\text { 06 Dec. } \\
\mathbf{2 0 2 0}\end{array}$ & $\begin{array}{l}\mathbf{2 4} \text { Dec. } \\
\mathbf{2 0 2 0}\end{array}$ & $\mathbf{2 0 2 1}$ & $\begin{array}{l}\text { 11 Manch } \\
\mathbf{2 0 2 1}\end{array}$ & $\begin{array}{l}\mathbf{1 7} \text { April } \\
\mathbf{2 0 2 1}\end{array}$ & $\begin{array}{l}\mathbf{2 8} \text { May } \\
\mathbf{2 0 2 1}\end{array}$ \\
\hline Haemoglobin & 8.4 & 7.7 & 9.6 & 8.2 & 8.1 & 8.5 & 8.8 \\
\hline $\begin{array}{l}\text { Blood Glucose } \\
\text { (Fasting) (mg/dl) }\end{array}$ & 130 & 162.8 & 162 & 156.7 & 130 & 126.1 & 96 \\
\hline
\end{tabular}

Diet

The patient was recommended to follow the diet plan which includes wheat, white and brown rice, onion, capsicum, tinda, pumpkin, reddish, squash, corn, pointed gourd, battle gourd, coriander leaves, mushroom, lettuce, turnip, rock salt, lotus stem, tomato, sponge gourd, fenugreek leaves, carrot, beetroot, French beans and ridge gourd and advised to excludes diets including all types of lentils, beans, pulses, milk products, dry fruits, white salt, wheat flour, besan, potato, lady finger, brinjal and taro root.

\section{Selection of Ayurvedic treatment}

Patient was administered with Ayurvedic medicines described in table no. 3 for the duration of six month of treatment

Table 3: Ayurvedic medicines prescribed to the patient in this case

\begin{tabular}{|l|l|l|l|l|}
\hline S.No. & $\begin{array}{l}\text { Ayurvedic } \\
\text { Intervention }\end{array}$ & Dosage form & Dose & Anupana \\
\hline 1. & $\begin{array}{l}\text { Dr.Shuddhi Immune } \\
\text { Tablets }\end{array}$ & Tablet & Twice a day & Normal Water \\
\hline 2. & Shudhikaran Tablet & Tablet & $\begin{array}{l}\text { One tablet repeated every week } \\
\text { for duration of } 40 \text { days }\end{array}$ & Lukewarm water \\
\hline 4. & Shudhikaran Powder & Powder & Once in a day $(2.5$ gm $)$ & Lukewarm water \\
\hline 5. & 32 Herbs Tea & Powder & 4- 5 times a day & Warm water \\
\hline 6. & Yakurt Shodh vatti & Tablets & Twice a day & Lukewarm water \\
\hline 7. & Mutra vardhak vatti & Tablet & Once day & Lukewarm water \\
\hline 8. & Kidney tonic & Liquid & Twice a day & --- \\
\hline 9. & Liver tonic & Liquid & Twice a day & --- \\
\hline
\end{tabular}


Ajeet Pratap Singh et al. Effective Management of Chronic Kidney Disease by Using Ayurvedic Interventions

\begin{tabular}{|l|l|l|l|l|}
\hline 10. & Relivion powder & Powder & Once in a day $(2.5 \mathrm{gm})$ & Lukewarm water \\
\hline 11. & Kidney care Churna & Powder & Once in a day $(2.5 \mathrm{gm})$ & Lukewarm water \\
\hline 12. & $\begin{array}{l}\text { Advanced Kidney Care } \\
\text { Capsules }\end{array}$ & Capsules & Once day & Normal Water \\
\hline 13. & Raktchaap vati Uri-go & Tablet & Once a day & Lukewarm water \\
\hline
\end{tabular}

\section{Follow-up and Outcomes}

Patient was followed up after every month from the start of Ayurvedic treatment. follow up was taken for time period of six months. Patient was advised to follow proper diet and medicines.

\section{Observations and result}

Hypertension and diabetes mellitus are the main causative factors of CKD. The presence of high glucose levels for prolonged period leads to the thickening of the glomerular basement membrane and mesangial expansion which further affects the glomerular filtration rate (GFR). Clinically this condition was diagnosed as Madhumeha and Mutra kshaya - a type of Mutraghata. After 7 months of treatment patient observed significant improvement in generalised weakness, appetite and low back pain. Clinically also significant improvement was observed in pedal edema and urine output. from the laboratory investigation, it was clearly observed that in six month of treatment period there was decrease in increased level of urea, creatinine and uric acid showing improved condition of kidney. Also, hemoglobin is maintained constant. Blood glucose level was also found to be reduced as compare to the initial condition of the patient. Results are shown in figure 1.

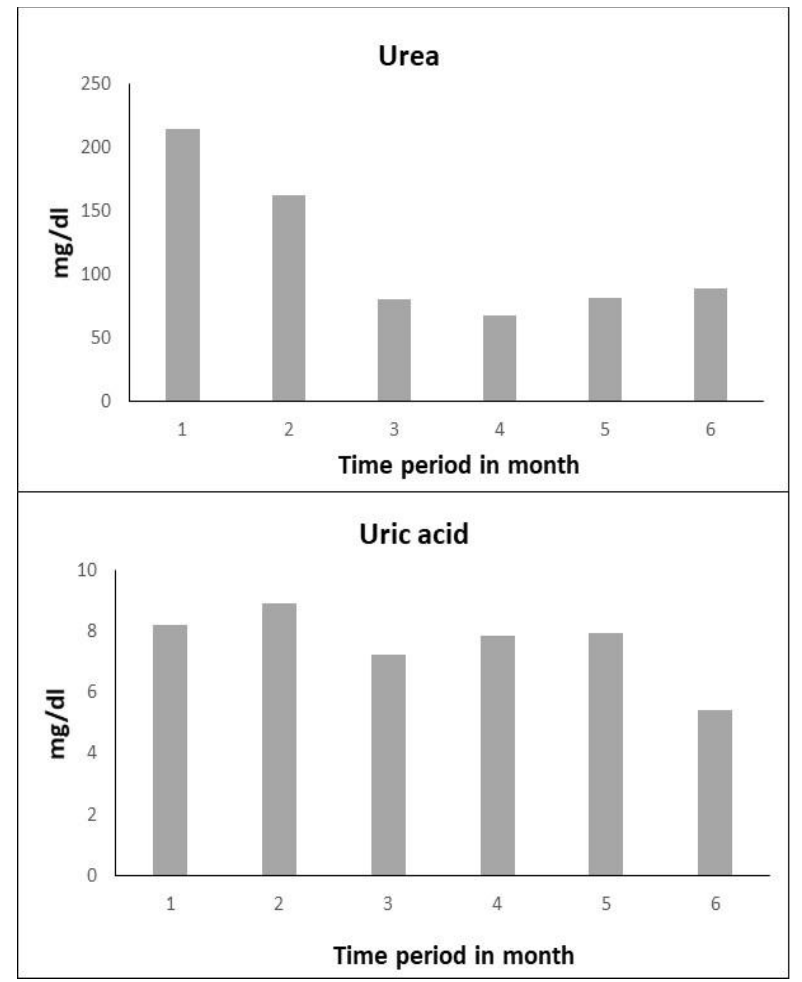

Figure 1: Graph showing results of Renal function test for 6 months period Ayurvedic treatment CONCLUSION

This case of chronic kidney disease, based on its presentation and Dosha involvement was diagnosed as Madhumeha and Mutrakshaya and it was treated according to the Chikitsa sutra of Mutraghtata. Mutrala and Tridosha shamaka mainly Kapha and Vata shamaka dravyas were used in the management of the disease. With the use Ayurveda medicines this condition was well managed and significant improvement was observed in this case, but such cases require frequent follow ups and regular medication until the serum creatinine levels comes under normal range.

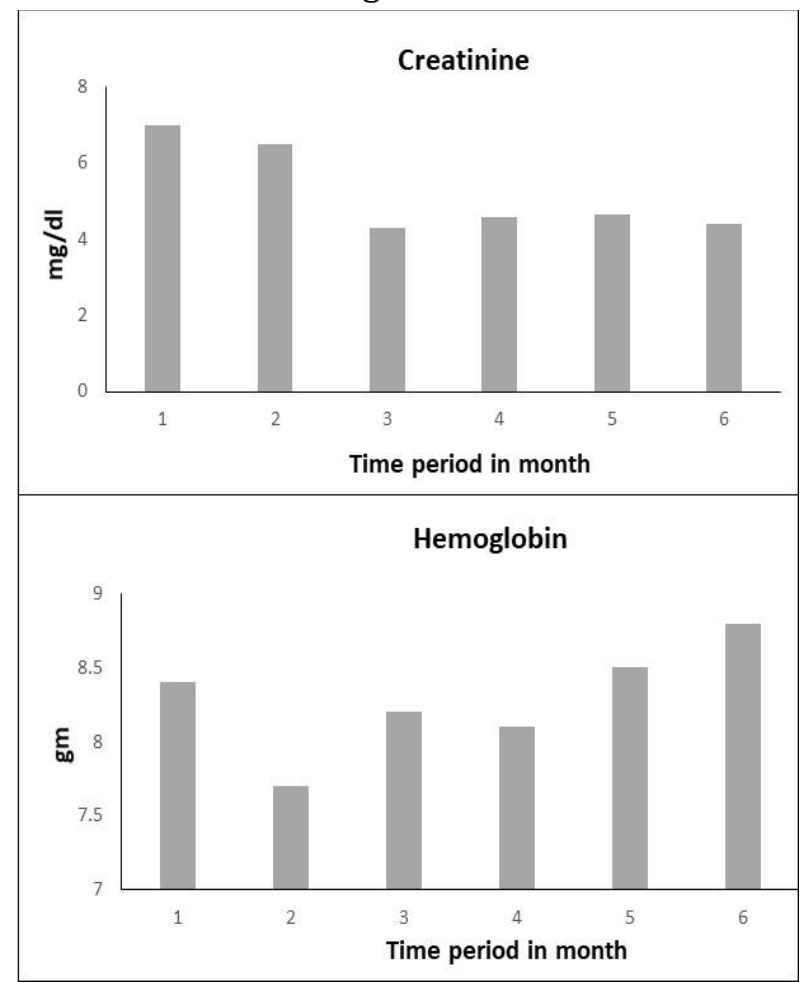
ACKNOWLEDGMENT

Authors are thankful to Acharya Manish Ji for providing opportunity for Shuddhi Ayurveda Clinic doctors for conducting case studies on their patients using Shuddhi Ayurveda herbal medicines.

\section{REFERENCES}

1. Naeem M, Ashraf A, Safdar HM, Khan MQ, Rehman SU, Iqbal R, Ahmad G. Biochemical changes in patients with chronic kidney failure in relation to complete blood count and anemia. IJB. 2020; 16(1):267-71.

2. Dare AJ, Fu SH, Patra J, Rodriguez PS, Thakur JS, Jha P, Million Death Study Collaborators. Renal failure 
deaths and their risk factors in India 2001-13: nationally representative estimates from the Million Death Study. The Lancet Global Health. 2017 Jan 1; 5(1):e89-95.

3. The WHO Newsroom Fact sheets - The top 10 causes of death. Published December 9, 2020. Source: WHO Global Health Estimates. Available at: https://www.who.int/newsroom/factsheets/detail/the-top-10-causes-of-death. Accessed March 26, 2021.

4. Bikbov B, Purcell CA, Levey AS, Smith M, Abdoli A, Abebe M, Adebayo OM, Afarideh M, Agarwal SK,

\section{Cite this article as:}

Ajeet Pratap Singh, Manish Grover, Avira Gautam. Effective Management of Chronic Kidney Disease by Using Ayurvedic Interventions: A Case Report. International Journal of Ayurveda and Pharma Research. 2021;9(7):26-30. https://doi.org/10.47070/ijapr.v9i7.1979

Source of support: Nil, Conflict of interest: None Declared
Agudelo-Botero M, Ahmadian E. Global, regional, and national burden of chronic kidney disease, 1990-2017: a systematic analysis for the Global Burden of Disease Study 2017. The Lancet. 2020 Feb 29; 395(10225):709-33.

5. Liyanage T, Ninomiya T, Jha V, Neal B, Patrice HM, Okpechi I, Zhao MH, Lv J, Garg AX, Knight J, Rodgers A. Worldwide access to treatment for end-stage kidney disease: a systematic review. The Lancet. 2015 May 16; 385(9981):1975-82.

Disclaimer: IJAPR is solely owned by Mahadev Publications - dedicated to publish quality research, while every effort has been taken to verify the accuracy of the content published in our Journal. IJAPR cannot accept any responsibility or liability for the articles content which are published. The views expressed in articles by our contributing authors are not necessarily those of IJAPR editor or editorial board members.

*Address for correspondence Avira Gautam

Shuddhi Ayurveda, Jeena Sikho Lifecare Pvt. Ltd. Chandigarh 140603, Punjab, India.

Email:

shuddhi.research@jeenasikho.co.in

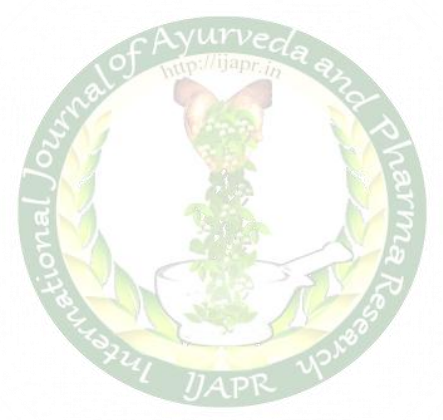

